\title{
46. 酸素濃度監視装置の改良
}

\section{1) 目的}

患者の呼吸ガスを測定することは患者管理の 上で一一重要である.とくに保育器内の酸素濃 度, 温度, 湿度等学長時閐沈わたって連続的に 監視することは，新生罗に対寸る環境军把握す るのに欠かすことのできない情報である。その ため現在，大気中の酸素潧度を測定する方法と して, Polarograph 法やガルバニ電池方式など が多く用いられて，すでに実用化されている。 今回著者らは，ガルバ二電池方式に基ずき，陰 極に Sn，陽極に Pt を用いた酸素濃度の測定 装置を試作したのでこの装置の特性について検 討した。

\section{2）酸素電極の測定原理および構造}

測定原理は酸素の溶けこんでいる電解筫溶液 に特定の 2 種の金属を浸し，その間で回路を構 成すれば，一方では還元反応，他方では酸化反 応が起こって電流が流れる，この電流值雨電 極間に与えられる印加電圧抢よび酸素濃度によ って変化するが，陽極の面積を小さくすること によって, 印加電圧の範囲 $(0.6 \mathrm{~V} \sim 0.8 \mathrm{~V})$ で は電流值は酸素濃度だけに反応して変化する。 しかし，電解質溶液および 2 種の金属電極を適 当に選ぶことにより，この印加電圧を自然電極 電位によって供給することができ，外部から何 らの電源も供給することはなしに上述の反応を 持続することができる，その時の電極反応式は

陽極 $(\mathrm{Pt}) \quad \mathrm{O}_{2}+2 \mathrm{H}_{2} \mathrm{O} \longrightarrow 4 \mathrm{OH}^{-}$

陰極 $(\mathrm{Sn}) \quad 2 \mathrm{Sn} \longrightarrow 2 \mathrm{Sn}^{++}+4 \mathrm{e}$

* 東京医科歯科大学医用器材研究所

** 東興化学研㮉
根本 銠*坓鼠健*田村俊世* 戸川達男*扪吉章浩**
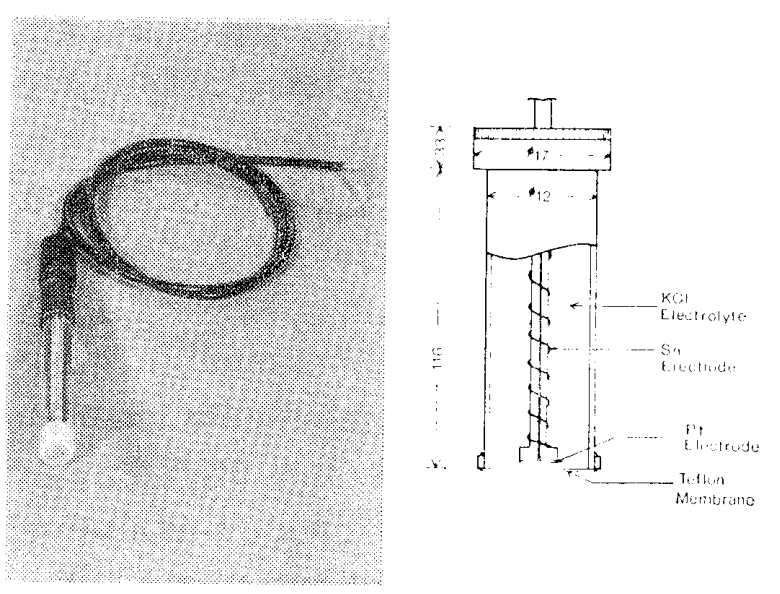

図 1 電極の外観と構造

$$
2 \mathrm{Sn}^{++}+4 \mathrm{OH}^{-} \longrightarrow 2 \mathrm{Sn}(\mathrm{OH})_{2}
$$

総括反心応

$$
\mathrm{O}_{2}+2 \mathrm{Sn}+2 \mathrm{H}_{2} \mathrm{O} \longrightarrow 2 \mathrm{Sn}(\mathrm{OH})_{2}
$$

で与寺られる。

この原理に基づいて，図 1 に示す構造で隔膜 式酸素電極㕝試作した。電極は，外套管ガラス $(116 \times 12 \phi)$ の中に, 電解質溶液 $(1 \mathrm{Mol} \mathrm{kcl})$ と陰極 $\mathrm{Sn}$, 陽極に $\mathrm{Pt}(3 \dot{\phi})$ を用いて, 電解 質溶液と外気との間をガス透過膜（テフロン 製，厚さ $25 \mu)$ によって分離されて抄り，外気 の酸素はこの膜を通って電解質溶液中に溶ける 構造になっている。

図2 は使用した電子回路を示し，駆動電源と して, ニッケルカドニウム電池 $(\mathrm{NR}-\mathrm{AA}$ 公称 容量 $450 \mathrm{mAh}$ ) 用い，回路の消費電流を約 $2.5 \mathrm{~mA}$ として，連続使用は 1 週間以上の測定 が可能で女る，回路構成は酸素電極電流増幅回 路, 温度検出回路, 温度補償回路から成り表示 は液㽞ディスプレイを用い, 酸素濃度表示は 0 〜100\%とした。 また，切換スイッチが室温(10 


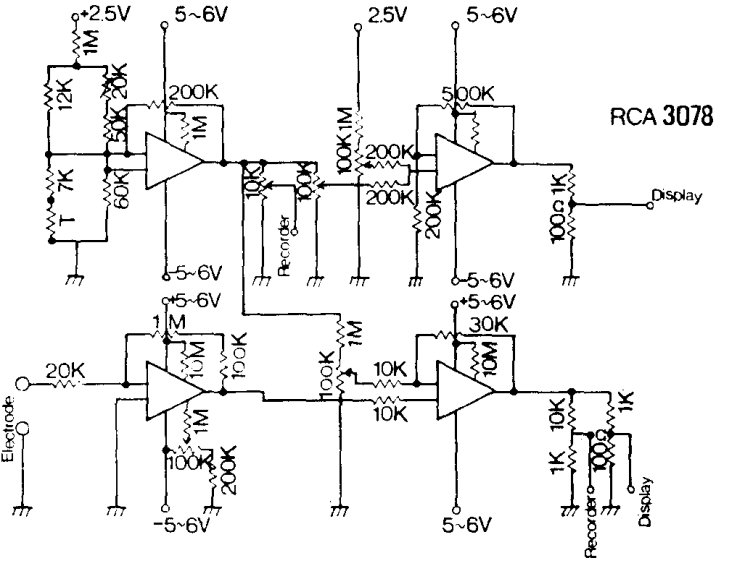

図2 電極測定回路

$\sim 35^{\circ} \mathrm{C}$ ）を表示でき, 外部出力電圧は $0 \sim 10$ $\mathrm{mV}$ とし記録計に接続できる.

\section{3）実験方法}

較正法は，チューブ内に電極を固定し電極隔 膜に窒素ガスを送吹し，その時の表示を０％之 し，また純酸素ガスを送吹した時を $100 \%$ とし て較正を行った。なお，大気中の酸素濃度（温 度 $20^{\circ} \mathrm{C}$ ，乾燥状態）が $20.9 \%$ を指示すること を確認した。

電極の温度, 湿度特性試験は恒温恒湿室内に おいて, 温度を $20^{\circ} \mathrm{C}, 25^{\circ} \mathrm{C}, 30^{\circ} \mathrm{C}, 35^{\circ} \mathrm{C}$ の 各温度において湿度を 20 〜 $100 \%$ に維持した時 の電極の電流值を測定して特性を表わした。 温度補償の方法は，電極隔膜における酸素ガ スの透過率が温度に支配されるため, 電極発生 電流が温度の影響を受けるので, サーミス夕電 極ガラスの外側に固定し, 室温 $20^{\circ} \mathrm{C}$ の時, サ 一ミスタブリッジの出力を 0 電位とし, 室温上 昇に伴う電極発生電流の增加率を打消す差分増 幅器を用いて温度補償を行った。

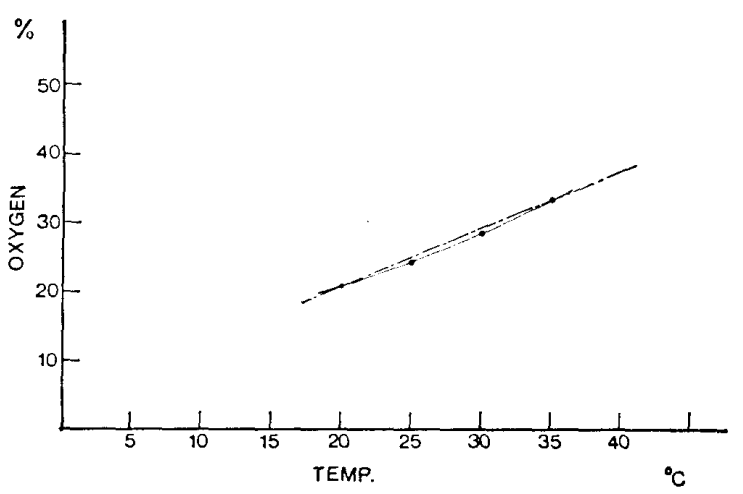

図 3 電極温度特性

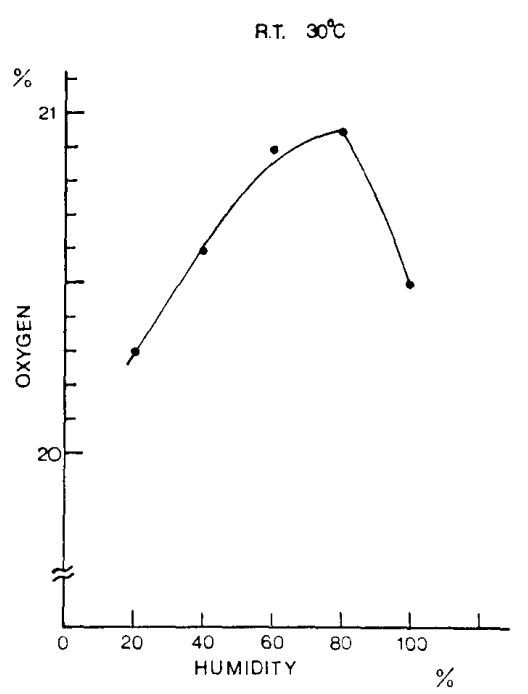

图 4 電極湿度特性

\section{4）結 果}

酸素電極の特性を図 3 , 図 4 に示し, 図 3 は 室温 $20^{\circ} \mathrm{C}$ の時, 大気中の酸素濃度を $20.9 \%$ と し, 温度飞 $25^{\circ} \mathrm{C}, 30^{\circ} \mathrm{C}, 35^{\circ} \mathrm{C}$ の各温度にお ける，電極発生電流の増加を濃度変化として表 わし, 温度 $15^{\circ} \mathrm{C}$ の差に対して, 濃度变化は約 60\%の増加を示している。

図 4 は, 温度 $30^{\circ} \mathrm{C}$ に一定に維持した条件下 で，湿度を20\%，40\%，60\%，80\%そして 100 \%に変化させた時の, 電極発生電流の変化を表 し，湿度が高くなっても電流値に対する影響が 少ないことを示している。

図 5 は，温度補償した測定回路を用いて，電 極を恒温恒湿室内放置した後, 温度を連続的 に変えた時の温度ドリフトを記録計で測定した 一部を示し，長時間安定な測定ができることを 表わしている. 図 6 は, 補償電極の温度変化に

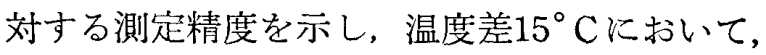
$\pm 1 \%$ 以内の精度で測定できることを示す。

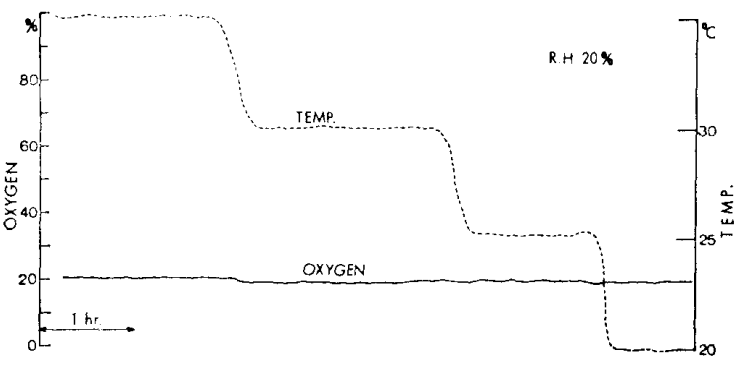

図 5 温度補㑽を行なった酸素鼌極の記録例 


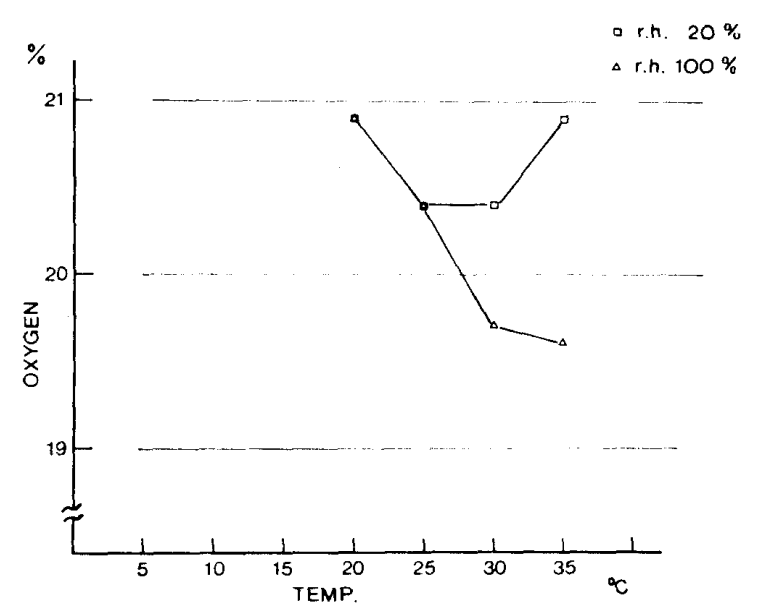

図 6 温度補償を行なった酸素電極の精度特性

5）検 討

今回われわれの試作した酸素電極の寿命は， 陰極材料に用いた Sn の量に依存するものであ るが，その特性実験として，酸素電極を酸素飽 和されていると考えられる井戸水(液温 $25^{\circ} \mathrm{C}$ ) 内に放置し, 単位発生電流の経日変化を求めた 結果, 発生電流は80日間以上, $0.85 \sim 0.82$ ( $\mu$ $\mathrm{A} / \mathrm{ppm}$ ) と安定した電流值を記録した。また, 電解質溶液と $\mathrm{Sn}$ の表面を洗浄することによ り，再度の測定ができ，測定寿命については問 題にはならないと考えられる。

态答時間においては，目標值のガス濃度を指 示するのに約 20 秒を要するが, 大気中のガス濃 度を測定するには十分な時間と思われる。

電極隔膜の交換は, 電極が棒状端面検出形構 造となっており先端検出部を取り外すことによ って隔膜の交換が従来の電極に比べると容易で ある。
測定精度においても，温度補償を行なうこと で温度 $20^{\circ} \mathrm{C}$ から $30^{\circ} \mathrm{C}$ まで, 測定精度を $\pm 1 \%$ 以内で検出できた。外気の湿度の影響は, 湿度 が高くなると，水蒸気圧が上昇して，大気中の 酸素分圧が減少するが，大気中の占める割合と して考えると無視できることになり，また，電 極隔膜も湿度の影響が少ないと思われる結果を 得て,この電極は湿度の影響はないと考えられ る.

以上の知見より，この酸素測定装置は実用で きると思われる。

付 議

\section{鳥取大麻酔科佐藤暢}

酸素濃度測定の精度については種々の面で注 目されており， 3 年程前に厳しい精度を決めた JISが測定されています。これは医療用という よりも主に酸欠防止用の労衝衛生用ですが，

J IS「酸素濃度計」の精度が出るとお考えです 加。

回答

東医歯大医用研 根 本鉄

われわれの検定は窒素ガスと純酸素ガスとの 2点検定しか行っていないため, 異った濃度值の 指示精度のデータはありませんが，大気濃度の 測定において温度補償精度を良くすれば， $\mathrm{O}_{2}$ 電 極の精度を考えて, J IS 精度 $\pm 0.7 \%$ を分満 足する精度が出せると思います。 